\title{
HER2/HER3 heterodimers and p21 expression are capable of predicting adjuvant trastuzumab response in HER2+ breast cancer
}

\author{
Andrew R. Green • Fabrício F. T. Barros • Tarek M. A. Abdel-Fatah • \\ Paul Moseley $\cdot$ Christopher C. Nolan • Alice C. Durham • Emad A. Rakha • \\ Stephen Chan · Ian O. Ellis
}

Received: 14 March 2014/Accepted: 17 March 2014/Published online: 6 April 2014

(C) The Author(s) 2014. This article is published with open access at Springerlink.com

\begin{abstract}
Human epidermal growth factor receptor 2 (HER2) plays an important role in breast cancer progression and provides predictive information for response to targeted therapy including trastuzumab although this is limited. Downstream pathways, such as PI3K/Akt, are associated with HER2/HER3 heterodimerization promoting survival and proliferation amongst cancer cells. Thus, patient outcome and trastuzumab therapy effectiveness might be further characterised by HER2/HER3 dimerisation and its signalling pathways. HER2/HER3 dimerisation status was assessed, using chromogenic in situ Proximity Ligation Assay, in two breast cancer series: early stage primary breast cancer, including 224 HER2+ patients that were not submitted to trastuzumab, and HER2+ breast cancer where patients were treated with adjuvant trastuzumab $(n=143)$. Levels of biomarkers including PI3K, pAKT, ER, PgR, HER3, BCL2, p53, PTEN and p21 were measured using immunohistochemistry. Levels of HER2/ HER3 heterodimers were compared with biomarker expression and patient outcome. An association between high levels of HER2/HER3 dimerisation and absence of
\end{abstract}

A. R. Green $(\square)$ · F. F. T. Barros · C. C. Nolan ·

A. C. Durham · E. A. Rakha · I. O. Ellis

Molecular Pathology Research Unit, Division of Cancer and

Stem Cells, School of Medicine, University of Nottingham,

Nottingham City Hospital, Nottingham NG5 1PB, UK

e-mail: andrew.green@nottingham.ac.uk

T. M. A. Abdel-Fatah · P. Moseley · S. Chan

Clinical Oncology, Nottingham University Hospitals NHS Trust,

City Hospital Campus, Nottingham NG5 1PB, UK

E. A. Rakha - I. O. Ellis

Department of Histopathology, Nottingham University Hospitals NHS Trust, City Hospital Campus, Nottingham NG5 1PB, UK hormone receptors, ER and PgR, was observed. We further show for the first time the presence of HER2/HER3 heterodimers and the loss of $\mathrm{p} 21$ expression in HER2+ breast cancer predicts a significantly poorer outcome when submitted to adjuvant trastuzumab. Breast cancer patients that reveal high levels of HER2/HER3 dimerisation and loss of p21 are associated with poor survival prognosis in patients with HER2+ breast cancer treated with adjuvant trastuzumab. Further quantification analysis of HER dimer/ ligand complexes and downstream signalling pathways will begin to unravel the complex associations with patient outcome and its relationship with sensitivity to targeted treatment.

Keywords Breast cancer - Trastuzumab - p21 - HER2/ HER3 heterodimers

\section{Introduction}

Breast cancer cases exhibiting overexpression of human epidermal growth factor receptor 2 (HER2) are correlated with poor patient survival [1-3]. HER family comprise four members, EGFR, HER2, HER3 and HER4 [4], which are part of the Type I group of receptor tyrosine kinases (RTKs) which have an important role regulating cell metabolism including migration, survival, adhesion, differentiation and proliferation $[5,6]$. However, HER2 and HER3 are not able to stimulate cell signalling as monomers as HER2 does not possess an ectodomain competent for interaction with any ligand, whereas HER3 lacks the kinase complex [7]. In order to activate downstream signalling cascades, it is compulsory that cooperation between these two receptors occurs resulting into an active heterodimer [8]. 
The frequency of HER2 overexpression is $13-23 \%$ in breast cancer and is associated with hormone receptor negative disease and thus associated with a poor prognosis [2, 4, 9] due to its aggressive behaviour and metastatic potential. [1, 3, 10]. Downstream pathways activated by overexpression of HER2 [11], include the RAS-MAPK pathway promoting proliferation, and the PI3K/Akt pathway resulting in apoptosis avoidance [7], angiogenesis [12], phospholipase $\mathrm{C} \gamma$ and signal transducer and activation of transcription (STATs) proteins [13].

HER3 is overexpressed in 10-30\% of breast cancer and is also associated with poor prognosis [4]. The absence of an activated tyrosine kinase domain is explained by the possession of mutations on four amino acids resulting in tyrosine low activity and the obligation of dimerisation to trigger the signalling cascade $[14,15]$. In breast carcinoma, the levels of HER3 can increase significantly when compared with normal cells due to overexpression, possibly instigated by protein translation or higher molecule halflife [16]. HER3 expression in breast cancer is highly associated with anti-apoptosis development by promotion of the PI3K signalling pathway [17].

Moreover, cell transformation and breast carcinoma progression might be triggered by HER 2 and HER 3 interaction [16] as this is the most common heterodimer associated with proliferative downstream pathways [15]. Therefore, the heterodimer HER2/HER3 could be essential to sustain a constitutive role of the PI3K downstream pathway [18].

HER2 + breast cancer patients are submitted to targeted therapy including trastuzumab (Herceptin ${ }^{\mathrm{TM}}$; Genentech; South San Francisco, CA). While trastuzumab interacts with HER2, the mechanism of action remains ill-defined. Despite the predictive value of HER2 positivity, only $35 \%$ of patients with HER2+ metastatic breast cancer show response when submitted to trastuzumab alone [19]. However, when trastuzumab is applied with first-line chemotherapy, the levels of success can increase up to $84 \%$ $[20,21]$. Therefore, alternative mechanisms that are not disturbed by trastuzumab alone might be implicated in carcinoma expansion [22]. Moreover, trastuzumab might be effective at initial treatments, however, after a period resistance increases substantially [23], even though the overall survival time might be expanded if a combination with chemotherapy takes place [24, 25].

We have previously used chromogenic in situ proximity ligation assay (PLA) to quantify and characterise the expression of HER2/HER3 heterodimers in a large series of breast cancers which showed that HER2/HER3 heterodimers were detected in $13.1 \%$ of all breast cancers and $73 \%$ of HER2 + tumours [26]. While HER2/HER3 dimers were associated with proliferation, distant metastasis and poor patient outcome, it did not discriminate divergent outcomes within HER2+ breast cancer or predict response to trastuzumab.
Therefore, in this study, we have further characterised HER2/HER3 dimerisation and investigated its association with the relevant pathways to increase our understanding of this complex system of cross-talk between receptors and whether this could affect patient outcome and trastuzumab therapy effectiveness.

\section{Materials and methods}

Patient samples

\section{Primary breast cancer series (unselected series)}

The patient series comprised 1,858 unselected primary operable invasive breast carcinoma cases, presenting between 1986 and 1998, from the well-characterised Nottingham-Tenovus primary breast carcinoma series [27-29]. Clinicopathological parameters for this series are summarised in Table 1.

\section{HER2 + trastuzumab nä̈ve series}

The HER2+ trastuzumab naïve series $(n=224)$ was composed by all HER2 positive cases part of unselected series. Clinicopathological parameters for this series are summarised in Table 1.

Biological characterisation, including immunoreactivity, marking and categorising of ER, progesterone receptor $(\mathrm{PgR})$, and Triple Negative Phenotype (TN) were delineated in there series as previously described [30-33].

\section{HER2+ adjuvant trastuzumab series}

The HER2 + adjuvant trastuzumab series consisted of 143 primary operable breast tumours from patients presenting between 2003 and 2010 who received adjuvant trastuzumab. Clinicopathological parameters for this series are summarised in Table 1.

\section{HER2+ series}

Combining the HER2+ adjuvant trastuzumab and HER2 + trastuzumab naïve series resulted in the HER2+ series, which included 367 patients. Clinicopathological parameters for this series are summarised in Table 1.

Immunohistochemistry and chromogenic in situ hybridisation

TMAs were prepared as previously described [30]. Immunohistochemistry was performed using novolink polymer detection systems (Leica) using primary 
Table 1 Clinicopathological characteristics of the unselected series $(n=1,858)$, HER2 + trastuzumab naïve series $(n=224)$, HER2 + adjuvant trastuzumab series $(n=143)$ and HER $2+$ Series $(n=367)$

\begin{tabular}{|c|c|c|c|c|}
\hline Characteristics & Unselected series & HER2 + (trastuzumab naïve) & HER2 + (adjuvant trastuzumab) & HER2 + (naïve + adjuvant) \\
\hline & $n(\%)$ & $n(\%)$ & $n(\%)$ & $n(\%)$ \\
\hline \multicolumn{5}{|c|}{ Age at diagnosis (years) } \\
\hline$<50$ & $601(32.4)$ & $82(36.6)$ & $61(43.6)$ & $143(39.3)$ \\
\hline$\geq 50$ & $1,256(67.6)$ & $142(63.4)$ & $79(56.4)$ & $221(60.7)$ \\
\hline \multicolumn{5}{|l|}{ Menopausal } \\
\hline Pre & $700(37.7)$ & $92(41.1)$ & $26(18.6)$ & $118(32.4)$ \\
\hline Post & $1,154(62.3)$ & $132(58.9)$ & $114(81.4)$ & $246(67.6)$ \\
\hline \multicolumn{5}{|l|}{ Death } \\
\hline No & $1,043(68.3)$ & $98(50.3)$ & $133(93.0)$ & $231(68.3)$ \\
\hline Yes & $483(31.7)$ & $97(49.7)$ & $10(7.0)$ & $107(31.7)$ \\
\hline \multicolumn{5}{|c|}{ Tumour size $(\mathrm{cm})$} \\
\hline$<1.5$ & $484(26.1)$ & $38(17.0)$ & $23(16.1)$ & $61(16.6)$ \\
\hline$\geq 1.5$ & $1,367(73.9)$ & $186(83.0)$ & $120(83.9)$ & $306(83.4)$ \\
\hline \multicolumn{5}{|l|}{ Tumour grade } \\
\hline 1 & $354(19.1)$ & $5(2.2)$ & $3(2.1)$ & $8(2.2)$ \\
\hline 2 & $616(33.3)$ & $33(14.8)$ & $37(25.9)$ & $70(19.1)$ \\
\hline 3 & $880(47.6)$ & $186(83.0)$ & $103(72.0)$ & $289(78.7)$ \\
\hline \multicolumn{5}{|c|}{ Lymph node Stage } \\
\hline 1 & $1,187(64.1)$ & $122(54.8)$ & $53(37.3)$ & $178(47.9)$ \\
\hline 2 & $505(27.3)$ & $67(30.0)$ & $56(39.4)$ & $123(33.7)$ \\
\hline 3 & $159(8.6)$ & $34(15.2)$ & $33(23.2)$ & $67(18.4)$ \\
\hline \multicolumn{5}{|c|}{ Distant metastasis } \\
\hline No & $1,288(69.7)$ & $122(54.5)$ & $124(87.9)$ & $246(67.4)$ \\
\hline Yes & $559(30.3)$ & $102(45.5)$ & $17(12.1)$ & $119(32.6)$ \\
\hline \multicolumn{5}{|c|}{ Vascular invasion } \\
\hline Negative & $1,061(58.2)$ & $118(53.4)$ & $79(56.0)$ & $197(54.4)$ \\
\hline Positive & $763(41.8)$ & $103(46.6)$ & $62(44.0)$ & $165(45.6)$ \\
\hline \multicolumn{5}{|l|}{ Relapse } \\
\hline No & $1,093(60.4)$ & $108(48.9)$ & $119(83.9)$ & $227(62.5)$ \\
\hline Yes & 718 (39.6) & $113(51.1)$ & $23(16.1)$ & $136(38.5)$ \\
\hline
\end{tabular}

antibodies (Table 2). TMA sections were counterstained with Mayer's haematoxylin.

Immunoreactivity of HER2 in TMA cores was scored using standard HercepTest guidelines (Dako). Chromogenic in situ Hybridisation (CISH) was used to quantify HER2 gene amplification using the HER2 FISH phar$\mathrm{mDx}^{\mathrm{TM}}$ plus HER2 CISH pharmDx ${ }^{\mathrm{TM}}$ kit (Dako) as previously described [26]. HER2 classification was assessed by using American Society of Clinical Oncology guidelines as previously described [26].
The expression of biomarkers were evaluated by assessing percentage staining and $\mathrm{H}$-score [34]. Only invasive cancer cells localised within tissue cores were considered and only cores exhibiting at least $15 \%$ of tumour cells were scored. TMAs were scored using highresolution digital images (NanoZoomer; Hamamatsu Photonics), at $\times 20$ magnification, using a web-based interface (Distiller; Slidepath Ltd.).

The REMARK guidelines were followed in the experimental procedures [35]. 
Table 2 Dilution, Source and pretreatment of antibodies used on both immunohistochemistry and in situ proximity ligation assay and the cut-off used to classify each biomarker

\begin{tabular}{|c|c|c|c|c|}
\hline Antibody [clone] & Dilution & $\begin{array}{l}\text { Incubation } \\
\text { time (min) }\end{array}$ & Source & $\begin{array}{l}\text { Cut-off } \\
(\%)\end{array}$ \\
\hline \multicolumn{5}{|c|}{ Hormone receptor proteins } \\
\hline ER [SP1] & $1: 50$ & 30 & Dako & 0 \\
\hline $\operatorname{PgR}[\mathrm{PgR} 636]$ & $1: 125$ & 30 & Dako & 0 \\
\hline \multicolumn{5}{|c|}{ Human epidermal growth factor receptor proteins } \\
\hline HER2 & $1: 400$ & 30 & Dako & $\begin{array}{l}\text { ASCO } \\
\text { guidelines }\end{array}$ \\
\hline \multicolumn{5}{|l|}{ Basal cytokeratins } \\
\hline $\begin{array}{l}\mathrm{CK} 5 / 6[\mathrm{D} 5 / 16 \\
\mathrm{B} 4]\end{array}$ & $1: 20$ & 30 & Dako & 10 \\
\hline CK14 [LL002] & $1: 100$ & 30 & Novocastra & 10 \\
\hline \multicolumn{5}{|c|}{ Cell Cycle associated proliferation and apoptosis related proteins } \\
\hline Ki67 [MB-1] & $1: 100$ & 30 & Dako & $10-50^{\mathrm{a}}$ \\
\hline $\mathrm{PI} 3 \mathrm{~K}$ & $1: 50$ & 60 & $\begin{array}{l}\text { Sigma } \\
\text { Aldrich }\end{array}$ & $30-100^{\mathrm{a}}$ \\
\hline $\mathrm{Akt}^{\mathrm{pS} 473}[14-5]$ & $1: 10$ & 30 & Dako & $60^{\mathrm{a}}$ \\
\hline P21 [SX118] & $1: 100$ & 30 & Dako & 0 \\
\hline Bcl-2 [124] & $1: 100$ & 30 & Dako & 30 \\
\hline \multicolumn{5}{|c|}{ Tumour suppressor genes } \\
\hline PTEN [6H2.1] & $1: 100$ & 60 & Dako & $10-100^{\mathrm{a}}$ \\
\hline P53 [DO7] & $1: 50$ & 30 & Novocastra & 5 \\
\hline $\begin{array}{l}\text { BRCA1 } \\
\text { [MS110] }\end{array}$ & $1: 100$ & 40 & Calbiochem & 100 \\
\hline \multicolumn{5}{|l|}{ Apomucins } \\
\hline $\begin{array}{l}\text { MUC-1 } \\
\text { [MA695] }\end{array}$ & $1: 350$ & 30 & Novocastra & $20-200^{\mathrm{a}}$ \\
\hline
\end{tabular}

${ }^{a}$ H-score

In situ proximity ligation assay (PLA)

Quantification of HER heterodimers was measured using in situ PLA for brightfield microscope as per the manufacturer's instructions (Duolink kit, Olink) as previously described [26]. $4 \mu \mathrm{m}$ TMA sections were mounted on $\mathrm{X}$-tra ${ }^{\mathrm{TM}}$ adhesive micro slide (Surgipath, Leica). Deparaffinization was performed, and heat-induced antigen retrieval was executed for $20 \mathrm{~min}$ in citrate buffer ( $\mathrm{pH}$ 6.0). Endogenous peroxidase was quenched using $0.3 \%$ hydrogen peroxide for $5 \mathrm{~min}$ and followed by a blocking solution for $30 \mathrm{~min}$ at $37^{\circ} \mathrm{C}$. To detect heterodimers, target antibodies from two different species were applied at previously determined optimal conditions. The anti-HER2 rabbit antibody (Dako, 1:200) and anti-HER3 mouse antibody (clone 2F12, Neomarkers, 1:40) were used, and incubated together for $30 \mathrm{~min}$ at room temperature (RT). This was followed by incubation with the PLA probe in a pre-heated humidity chamber for $90 \mathrm{~min}$ at $37^{\circ} \mathrm{C}$. Hybridisation/ligation incubation took place for $30 \mathrm{~min}$ and amplification for $120 \mathrm{~min}$ at $37^{\circ} \mathrm{C}$. To detect hybridisation, Horse Radish Peroxidase was used and incubated for $30 \mathrm{~min}$ at RT followed by appliance of substrate solution for $10 \mathrm{~min}$ at RT. Counterstaining was performed using Duolink ${ }^{\circledR}$ nuclear staining for 2 min at RT followed by washing the slides under running tap water for 10 min. Slides were mounted with a coverslip after dehydration of the sections.

Image analysis

To quantify the HER2/HER3 heterodimers, image analysis was employed using Duolink ${ }^{\circledR}$ ImageTool (Olink, Sweden). High-resolution images of TMA sections were acquired at $\times 40$ magnification (NanoZoomer).

One observer (FFTB) scored all IHC and PLA results, which were rescored arbitrarily revealing a high concordance between both occasions.

Statistical analysis

All statistical analyses were performed using SPSS 19.0 (SPSS Inc., Chicago, Illinois). Pearson's $\chi^{2}$ association analysis was employed in support of inter-relationships between HER2/HER3 dimerisation occurrence status with clinicopathological parameters, and biomarkers. For any relationship to be considered significant, a $p$ value of $<0.05$ was used.

Ethics

Nottingham Research Ethics Committee 2 approved this research project under the title of 'Development of a molecular genetics classification of breast cancer.'

\section{Results}

HER2/HER3 heterodimers and correlation with biomarkers

Table 3 summarises the correlations between HER2/HER3 dimer levels and biomarkers of importance in breast cancer. In the unselected series, a significant positive correlation was observed between high levels of HER2/HER3 heterodimer expression with pAkt $(p=0.044)$, PI3K $(p<0.001)$, p53 $(p<0.001)$ and PTEN $(p=0.006)$. There was a negative association between HER2/HER3 heterodimer expression and Bcl-2, BRCA1 $(p=0.005)$, $\mathrm{ER}, \mathrm{PgR}($ all $p<0.001)$ and MUC-1 $(p=0.020)$.

Within the HER2 + series, there were similar correlations but an association with p21 $(p=0.027)$ and lack of correlation with PTEN and p53 were observed. 
Table 3 Association of HER2/HER3 dimerisation levels with biomarker expression in breast cancer

\begin{tabular}{|c|c|c|c|c|c|c|}
\hline \multicolumn{7}{|c|}{ HER2/HER3 Status } \\
\hline \multirow[t]{2}{*}{ Biomarker } & \multicolumn{3}{|c|}{ Unselected series } & \multicolumn{3}{|l|}{ HER2+ series } \\
\hline & Low $(\%)$ & High (\%) & $p$ value $\left(\chi^{2}\right)$ & Low $(\%)$ & High (\%) & $p$ value $\left(\chi^{2}\right)$ \\
\hline \multicolumn{7}{|l|}{ Bcl-2 } \\
\hline Negative & $207(41.0)$ & $53(75.7)$ & $<0.001(29.925)$ & $32(47.1)$ & $80(66.1)$ & $0.010(6.549)$ \\
\hline Positive & $298(59.0)$ & $17(24.3)$ & & $36(52.9)$ & $41(33.9)$ & \\
\hline \multicolumn{7}{|l|}{ pAkt } \\
\hline Negative & $121(25.4)$ & $11(15.5)$ & 0.044 (3.295) & $11(29.7)$ & $11(19.6)$ & $0.263(1.255)$ \\
\hline Positive & $356(74.6)$ & $60(84.5)$ & & $26(70.3)$ & $45(80.4)$ & \\
\hline \multicolumn{7}{|l|}{ PI3K } \\
\hline Negative & $122(22.1)$ & 7 (8.6) & $<0.001(15.942)$ & $4(5.8)$ & $5(3.7)$ & $0.105(4.512)$ \\
\hline Moderate & $143(25.9)$ & $13(16.0)$ & & $12(17.4)$ & $11(8.2)$ & \\
\hline Strong & $288(52.0)$ & $61(75.3)$ & & $53(76.8)$ & $118(88.1)$ & \\
\hline \multicolumn{7}{|l|}{ p21 } \\
\hline Negative & $99(79.2)$ & $10(90.9)$ & $0.351(0.871)$ & $17(45.9)(2.9)$ & $12(23.5)$ & $\mathbf{0 . 0 2 7}(4.877)$ \\
\hline Positive & $26(20.8)$ & $1(9.1)$ & & $20(54.1)$ & $39(76.5)$ & \\
\hline \multicolumn{7}{|l|}{ MUC-1 } \\
\hline Negative & $69(12.9)$ & $2(2.6)$ & $\mathbf{0 . 0 2 0}(7.834)$ & $4(5.6)$ & $4(3.1)$ & $0.581(0.581)$ \\
\hline Moderate & $243(45.3)$ & $43(56.6)$ & & $39(54.9)$ & $66(52.0)$ & \\
\hline Strong & $224(41.8)$ & $31(40.8)$ & & $28(39.4)$ & $57(44.9)$ & \\
\hline \multicolumn{7}{|l|}{ BRCA1 } \\
\hline Negative & $317(61.0)$ & 59 (77.6) & $\mathbf{0 . 0 0 5}(7.913)$ & $48(72.7)$ & $85(69.1)$ & $0.603(0.270)$ \\
\hline Positive & $203(39.0)$ & $17(22.4)$ & & $18(27.3)$ & $38(30.9)$ & \\
\hline \multicolumn{7}{|l|}{ p53 } \\
\hline Negative & 435 (71.7) & $46(48.9)$ & $<0.001(19.524)$ & $27(36.0)$ & $45(31.5)$ & $0.499(0.457)$ \\
\hline Positive & $172(28.3)$ & $48(51.1)$ & & $48(64.0)$ & $98(68.5)$ & \\
\hline \multicolumn{7}{|l|}{ PTEN } \\
\hline Weak & $79(22.8)$ & $3(5.5)$ & 0.006 (10.092) & $0(0.0)$ & $5(5.7)$ & $0.265(2.653)$ \\
\hline Moderate & $130(37.5)$ & $21(38.2)$ & & $21(53.8)$ & $40(45.5)$ & \\
\hline Strong & $138(39.8)$ & $31(56.4)$ & & $18(46.2)$ & 43 (48.9) & \\
\hline \multicolumn{7}{|l|}{ ER } \\
\hline Negative & $169(28.3)$ & $56(60.2)$ & $<0.001(37.424)$ & $23(31.1)$ & $91(62.8)$ & $<\mathbf{0 . 0 0 1}(19.699)$ \\
\hline Positive & 429 (71.7) & $37(39.8)$ & & $51(68.9)$ & $54(37.2)$ & \\
\hline \multicolumn{7}{|l|}{ PgR } \\
\hline Negative & $264(44.2)$ & $65(70.7)$ & $<0.001(22.321)$ & $36(48.6)$ & $100(71.4)$ & $\mathbf{0 . 0 0 1}(10.845)$ \\
\hline Positive & $333(55.8)$ & $27(29.3)$ & & 38 (51.4) & $40(28.6)$ & \\
\hline
\end{tabular}

Bold values indicate significant values $(p<0.005)$

Representative tumours showing HER2/HER3 heterodimers and p21 expression are shown in Fig. 1.

Association of HER2/HER3 heterodimers with patient outcome

HER2/HER3 heterodimers were associated with poor patient outcome (BCSS and DFI) in the unselected series but not in the HER2 + naïve or HER2 + trastuzumab series
(Fig. 2). Kaplan-Meier survival analyses showed that BCSS and DFI outcome of those cases submitted to adjuvant trastuzumab treatment against trastuzumab naïve patients which revealed a significantly better patient outcome in patients receiving trastuzumab $(p<0.001$, data not shown).

Further analysis showed that amongst the ER-positive population in the unselected series, high HER2/HER3 dimerisation was significantly associated with shorter BCSS and DFI in both the short (5 years) and long (maximum 
26 years, median 11 years) term (Fig. 3). A multivariate Cox regression model, including tumour size, tumour stage and tumour grade, revealed that high levels of HER2/HER3 amongst the ER-positive patients were independently associated with worse BCSS $(H R=0.46,95 \%$ CI $0.29-0.74, \quad p=0.001$, Table 4) but not with DFI $(H R=0.67,95 \%$ CI $0.43-1.06, p=0.087)$. There was no
Fig. 2 BCSS and DFI analysis for HER2/HER3 heterodimer status. Unselected series (a, b), trastuzumab Naïve Series (c, d) and trastuzumab adjuvant series $(\mathbf{e}, \mathbf{f})$

correlation between HER2/HER3 heterodimer and patient outcome in the ER-negative population of the unselected series for both short- and long-term BCSS (Fig. 3). There
Fig. 1 p21and HER2/HER3 heterodimer expression in two HER 2 + breast tumours. p21 expression: $\mathbf{a}$, low and $\mathbf{b}$, high at $10 \times$ magnification. HER2/ HER3 heterodimer expression: High expression (c, $10 \times$ magnification; e, $40 \times$ magnification) and low expression $(\mathbf{d}, 10 \times 21$ magnification; f, $40 \times$ magnification)
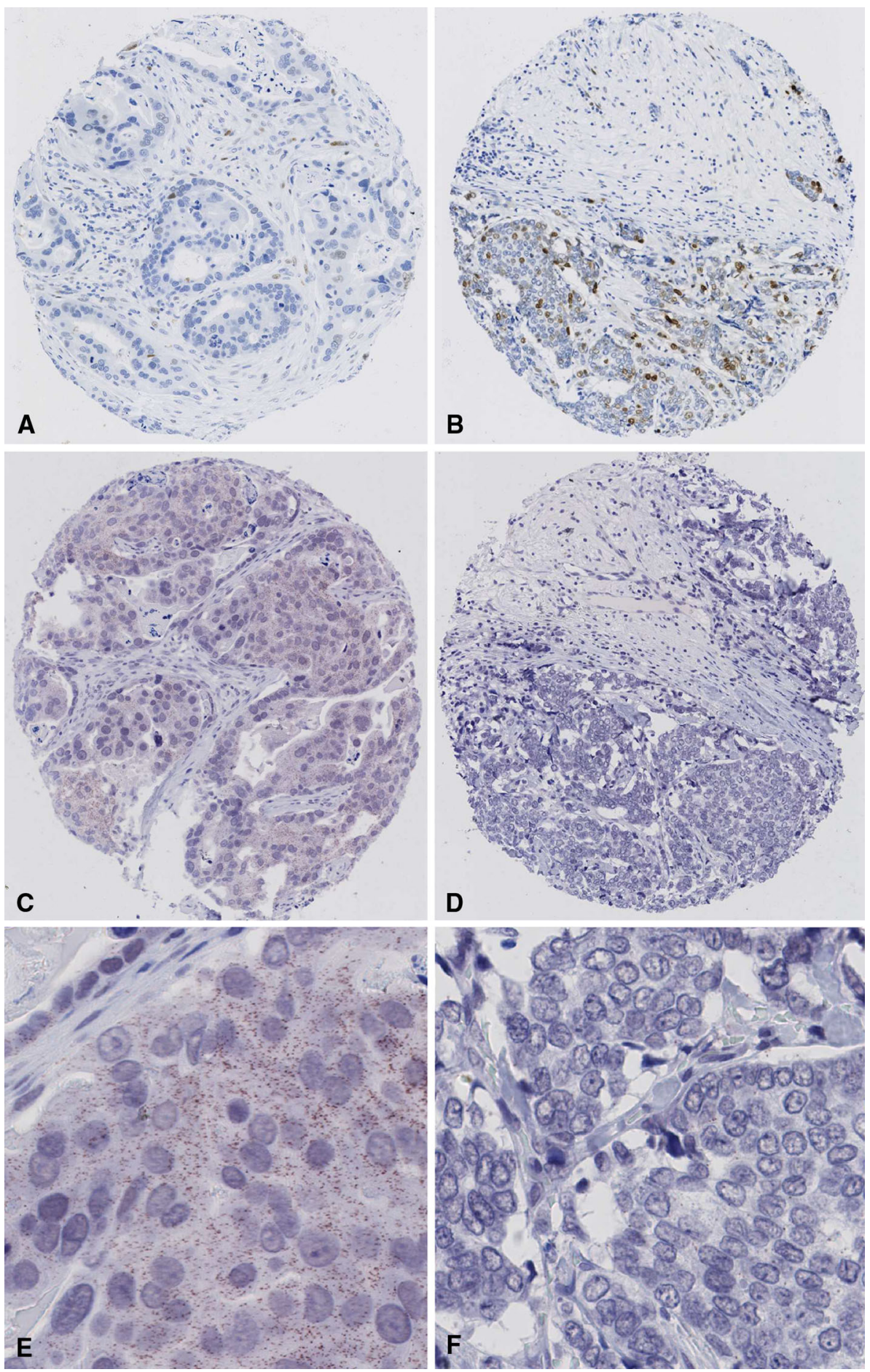


\section{Unselected Series}
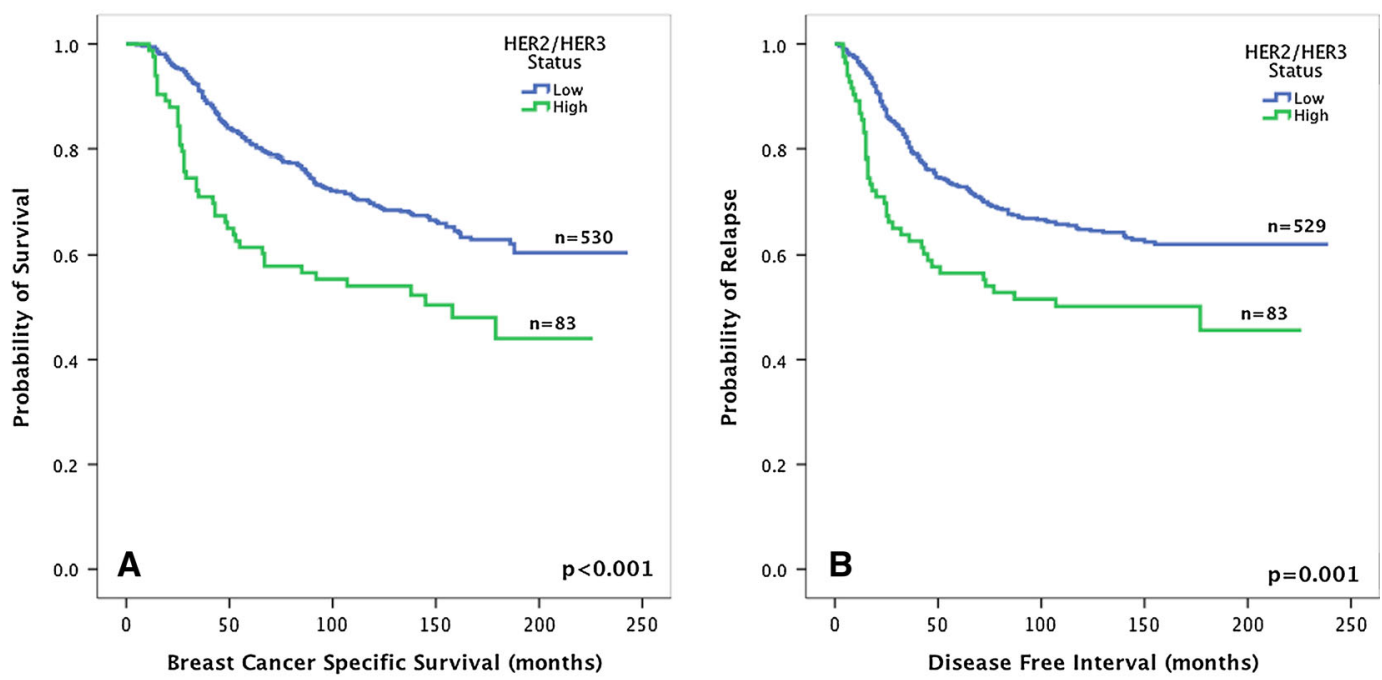

Trastuzumab Naïve Series
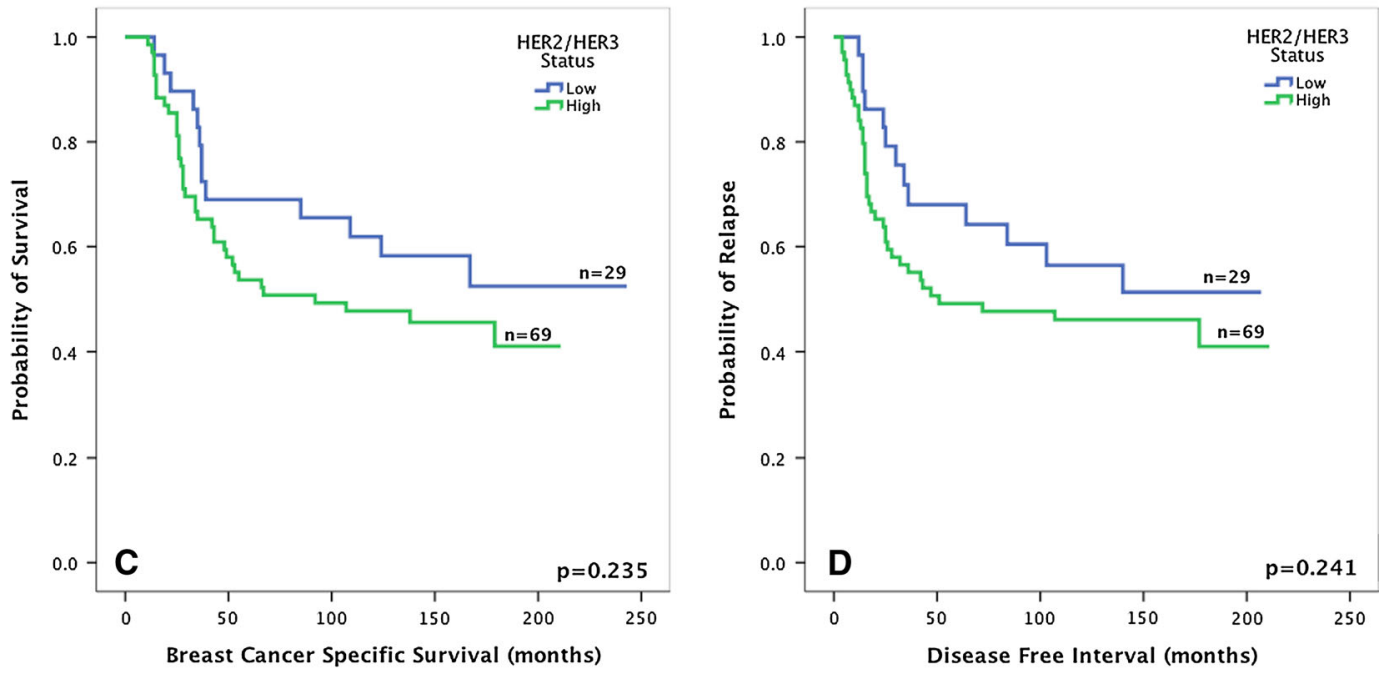

Trastuzumab Adjuvant Series
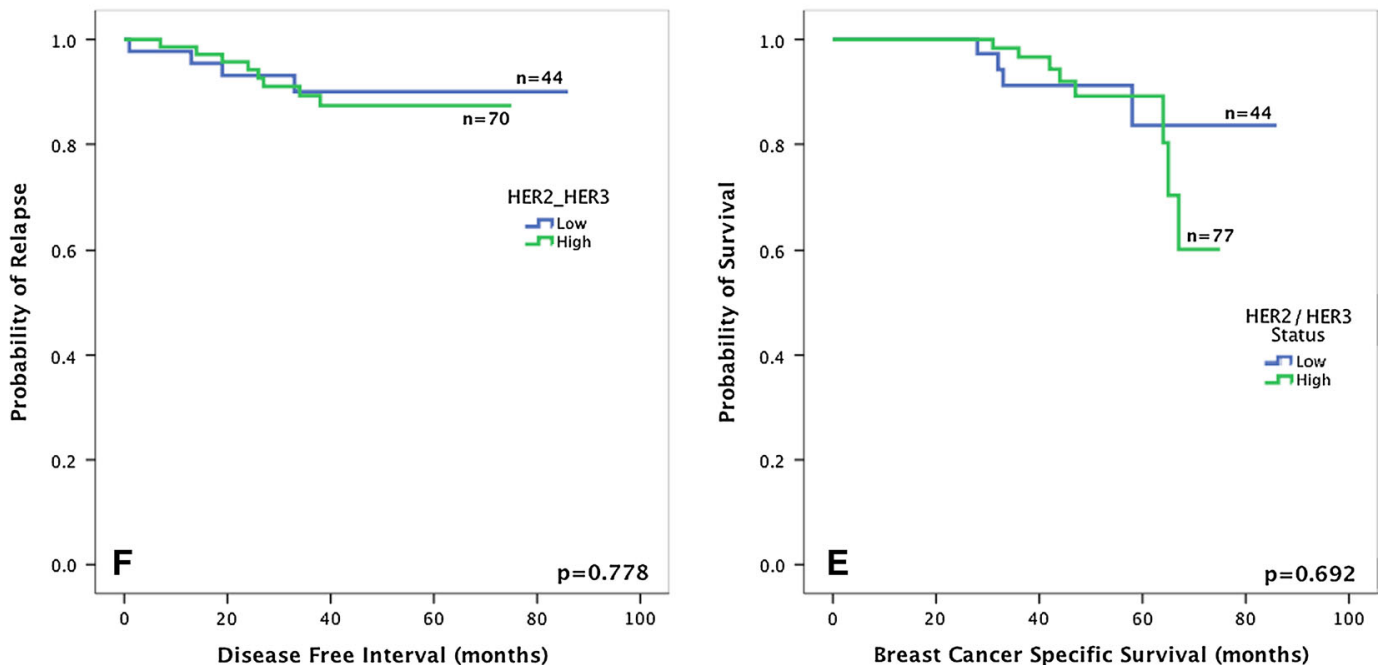
was likewise no association with BCSS in either ERpositive or ER-negative expression with high levels of HER2/HER3 heterodimers in the HER2+ naïve or trastuzumab series.

In the HER2+ trastuzumab series, there was a significantly better overall survival of patients who had high levels
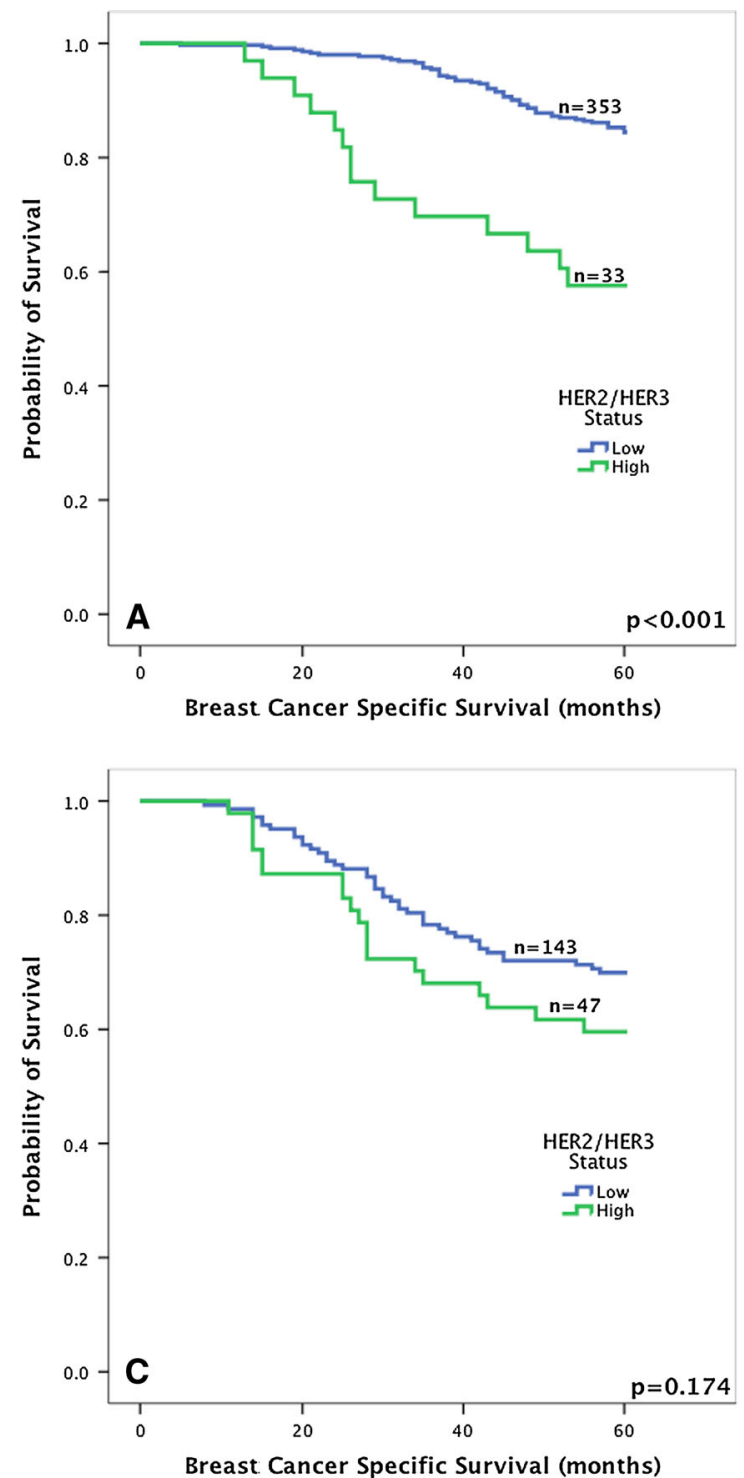

of HER2/HER3 dimersation but were negative for $\mathrm{p} 21$ expression compared with patients who were either p21 positive or did not have HER2/HER3 dimerisation ( $p=0.001$, Fig. $4 a)$. A similar observation was made with disease-free interval ( $p=0.015$, Fig. $4 b)$. There were no other associations in the HER2 + trastuzumab or naïve series
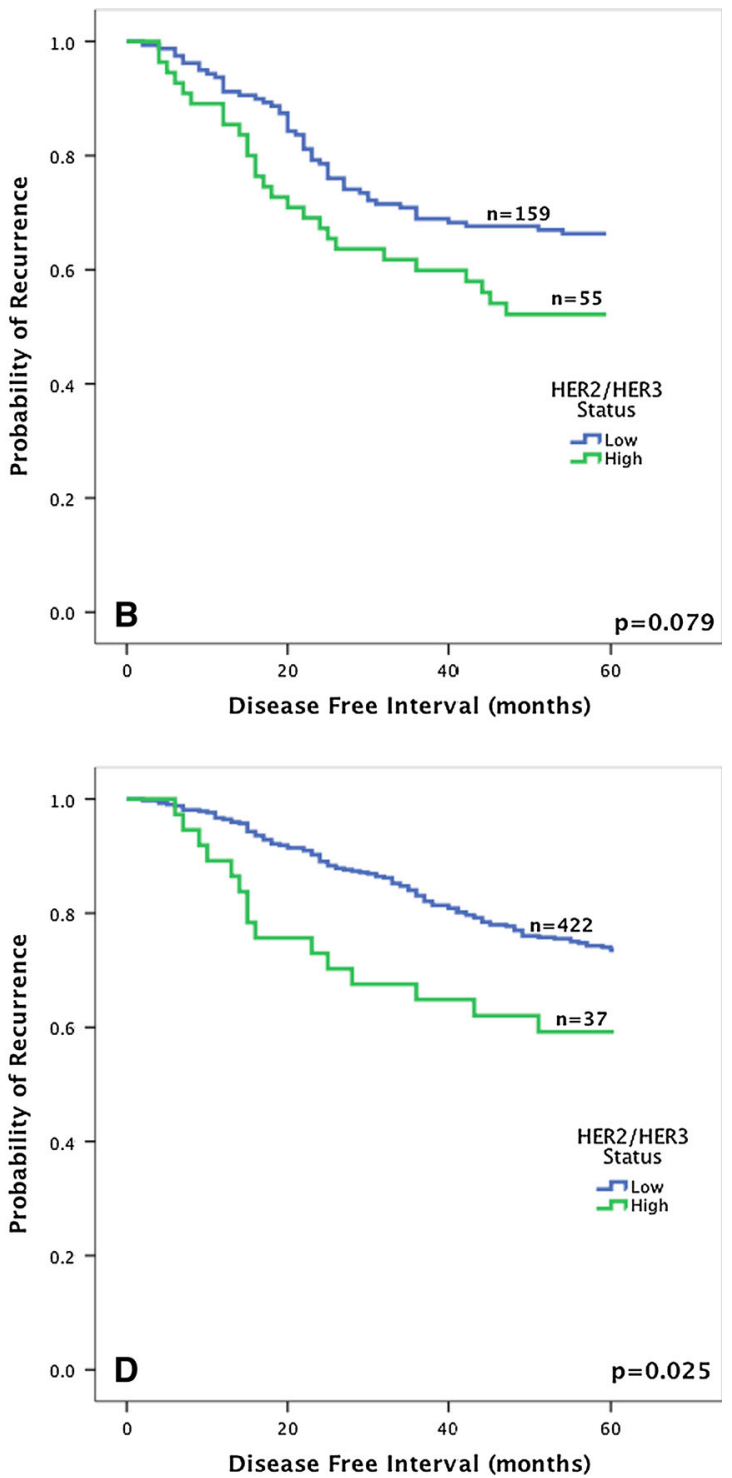

Fig. 3 HER2/HER3 heterodimer expression in unselected breast cancer and patient outcome. ER positive (a, b) and ER negative (c, d) tumours for BCSS and DFI

Table 4 Multivariate Cox regression analysis of factors associated with BCSS and DFI for ER-positive cases in the unselected series

\begin{tabular}{llrllr}
\hline Variable & \multicolumn{1}{l}{ BCSS } & & DFI & \\
\cline { 2 - 2 } & Hazard ratio $(95 \% \mathrm{CI})$ & $\mathrm{p}$ value & & Hazard ratio $(95 \% \mathrm{CI})$ & $\mathrm{p}$ value \\
\hline Tumour size $(\mathrm{cm})$ & $0.48(0.28-0.85)$ & 0.011 & & $0.57(0.38-0.85)$ & 0.007 \\
Tumour stage & $1.69(1.33-2.16)$ & $<0.001$ & & $1.61(1.30-1.99)$ & $<0.001$ \\
Tumour grade & $1.77(1.37-2.30)$ & $<0.001$ & & $1.22(0.99-1.49)$ & 0.059 \\
HER2/HER3 heterodimer & $0.46(0.29-0.74)$ & 0.001 & & $0.67(0.43-1.06)$ & 0.087
\end{tabular}



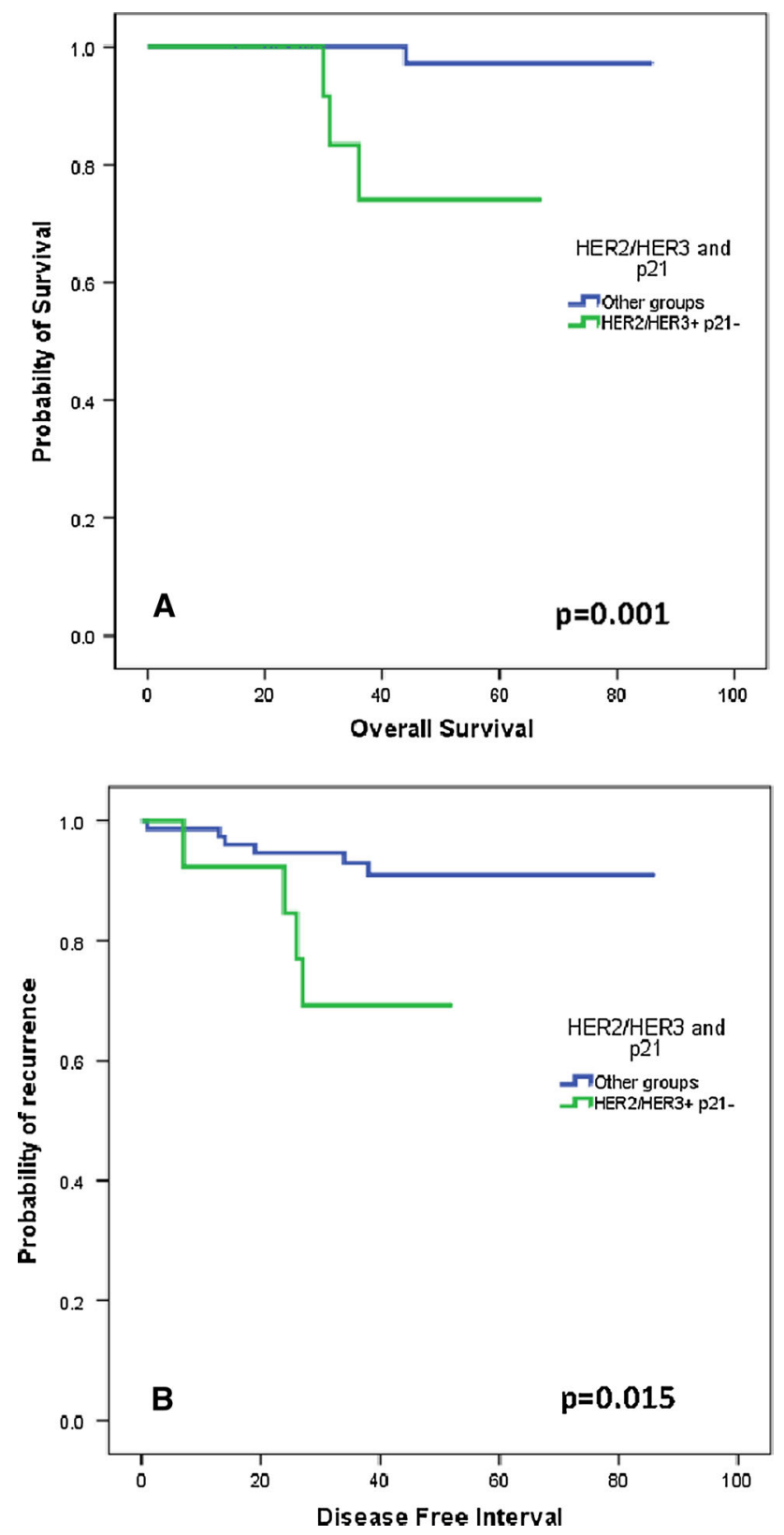

Fig. 4 Patient outcome with respect to HER2/HER3 and p21 status in HER2+ breast cancer treated with trastuzumab. Overall survival (a) and disease-free interval (b). HER2/HER3 + p21- $(n=13)$, Other groups: HER2/HER2 + p21 +, HER2/HER3- p21 +, HER2/ HER3-p21- $(n=75)$. Time in months

with either OS or PFS between HER2/HER3 heterodimers and the other biomarkers investigated in this study.

\section{Discussion}

HER2/HER3 heterodimers have been described as to be the major interaction in HER2-amplified breast carcinomas [36]. We and others have observed that approximately $70 \%$ of all HER $2+$ tumours demonstrate HER2/HER3 heterodimers [26, 37]. Where HER3 interacts with HER2, downstream pathways responsible for proliferation and survival are triggered [38], also stimulating creation of metastases [39]. Therefore, in this study, chromogenic PLA was utilised to detect HER2/HER3 dimerisation levels in archival primary formalin-fixed breast carcinomas including HER2+ breast cancer, either receiving only chemotherapy or adjuvant trastuzumab and chemotherapy. Investigating HER2/HER3 dimers, along with downstream targets using IHC, aimed to improve and provide further detailed information of the biology of HER2+ disease and the mechanisms of targeted treatments and resistance.

HER2/HER3 develops an important role in promotion of cell proliferation and apoptosis avoidance [40]. Even though HER2/HER3 heterodimers were not associated with the cell proliferation marker, Ki67 [41] it was negatively associated with $\mathrm{Bcl}-2$, which is highly correlated with apoptosis avoidance [42]. As a monomer, HER2 is not competent of interacting with PI3K subsequently activating the PI3K/Akt pathway. However, the HER2/HER3 heterodimer is favourably efficient performing it, which was confirmed by the strong association with both Akt and PI3K expression. This role is stimulated by HER3 that contains six tyrosine-binding points with the highest affinity for PI3 K amongst the HER family [17, 43, 44]. Therefore, instigation of HER3 results in a durable and strong trigger of the downstream PI3 K/Akt cascade [45]. Additionally, the high association of HER2/HER3 heterodimers with CK18 supports the idea that apoptosis does not take place amongst these cells due to CK18 high levels of degradation being associated with apoptosis [46, 47]. HER2/HER3 was also associated with strong levels of MUC-1, which is associated with poor prognosis amongst the breast cancer patients being described to be connected with the metastases progression process $[48,49]$.

Interestingly, it was observed that low HER/HER3 dimerisation levels were associated with ER and PR positivity. This fact is in concordance to those studies suggesting an absence of HER2 overexpression when hormone receptors are present in cancer cells [10, 50]. The high association between ER and BCL-2 is already documented [42] and observed in this study which might explain the poor outcome observed amongst those patients revealing high levels of HER2/HER3 and ER+ status. Moreover, the multivariate analysis revealed HER2/HER3 high levels as an independent prognostic factor for both BCSS and DFI. This finding is in concordance to the previous study [51], supporting the idea that this proteinprotein interaction may deliver additional prognostic information to that obtained by HER2 gene amplification status. For those patients with negative ER status, no 
significant difference was observed regarding HER2/ HER3. This indicates an inverse association between the dimerisation status and the expression of the hormone receptors, supporting the idea of a negative regulation of HER2 in the presence of hormone receptors [52], even though it can be partially reversible [50].

We have previously shown that the presence of HER2/ HER3 heterodimers alone did not reveal a significant prognostic prediction in HER2+ breast cancer treated with adjuvant trastuzumab [26]. We show for the first time, the presence of HER2/HER3 heterodimers and the loss of p21 expression in HER2+ breast cancer predict a significantly poorer outcome when submitted to adjuvant Trastuzumab. Trastuzumab has been shown to interfere HER2+ intracellular signalling by inhibiting DNA damage repair, inducing cell cycle arrest and inhibiting tumour angiogenesis. There is conflicting in vitro data whether Trastuzumab directly affects DNA damage repair modulated by p21. A study by Pietras et al. [19] showed that it decreased p21 expression thereby promoting DNA damage, whereas another study showed little change in p21 levels [53]. However, there is stronger evidence that HER 2 amplification or Trastuzumab promotes the cellular localisation of p21 thereby affecting the inhibition of cell proliferation [53-55], although in the current study, only nuclear p21 expression was taken into account.

In conclusion, loss of p21 expression mediated through HER2/HER3 heterodimerization is associated with poor outcome in patients with HER2 + breast cancer treated with adjuvant Trastuzumab. Incorporating further analysis in a larger series with longer follow-up is most likely to assist in qualifying this hypothesis. Additionally, characterisation of the ligands amongst HER2+ breast cancer is urgently required to create a more robust classification method in order to avoid high levels of unsuccessfully therapy.

Acknowledgments We would like to thank the University of Nottingham for funding the Studentship.

Competing interests The authors declare that they have no competing interests.

Open Access This article is distributed under the terms of the Creative Commons Attribution Noncommercial License which permits any noncommercial use, distribution, and reproduction in any medium, provided the original author(s) and the source are credited.

\section{References}

1. Yu DH, Hung MC (2000) Overexpression of ErbB2 in cancer and ErbB2-targeting strategies. Oncogene 19(53):6115-6121

2. Slamon DJ, Clark GM, Wong SG, Wendy J. Levin, Axel Ullrich WLM (1987) Human Breast Cancer: Correlation of Relapse and Survival with Amplification of the HER-2lneu Oncogene. Science:177-183
3. Weinberg RA (2007) The biology of cancer. Garland Science

4. Witton CJ, Reeves JR, Going JJ, Timothy GC, Bartlett JM (2003) Expression of the HER1-4 family of receptor tyrosine kinases in breast cancer. J Pathol 200:290-297. doi:10.1002/ path. 1370

5. Gschwind A, Fischer OM, Ullrich A (2004) The discovery of receptor tyrosine kinases: targets for cancer therapy. Nat Rev Cancer 4(5):361-370. doi:10.1038/nrc1360

6. Vandergeer P, Hunter T, Lindberg RA (1994) Receptor proteintyrosine kinases and their signal-transduction pathways. Annu Rev Cell Biol 10:251-337

7. Yarden Y, Sliwkowski MX (2001) Untangling the ErbB signalling network. Nat Rev Mol Cell Biol 2(2):127-137

8. Dawson JP, Berger MB, Lin CC, Schlessinger J, Lemmon MA, Ferguson KM (2005) Epidermal growth factor receptor dimerization and activation require ligand-induced conformational changes in the dimer interface. Mol Cell Biol 25(17):7734-7742. doi:10.1128/mcb.25.17.7734-7742.2005

9. Koninki K, Tanner M, Auvinen A, Isola J (2009) HER-2 positive breast cancer: decreasing proportion but stable incidence in Finnish population from 1982 to 2005. Breast Cancer Res. doi:10. $1186 /$ bcr2322

10. Watanabe T, Fukutomi T, Tsuda H, Adachi I, Nanasawa T, Yamamoto H, Abe K (1993) Determination of c-Erbb-2 protein in prymary breast-cancer tissue-extract using an enzyme-immunoassay. Jpn J Cancer Res 84(12):1279-1286

11. Linggi B, Carpenter G (2006) ErbB receptors: new insights on mechanisms and biology. Trends Cell Biol 16(12):649-656. doi: $10.1016 /$ j.tcb. 2006.10 .008

12. Yen L, You XL, Al Moustafa AE, Batist Gerald, Nancy E, Hynes Sylvie Mader, Meloche S, Alaoui-Jamali MA (2000) Heregulin selectively upregulates vascular endothelial growth factor secretion in cancer cells and stimulates angiogenesis. Oncogene 19:3460-3469

13. Miaczynska M, Pelkmans L, Zerial M (2004) Not just a sink: endosomes in control of signal transduction. Curr Opin Cell Biol 16(4):400-406. doi:10.1016/j.ceb.2004.06.005

14. Carpenter G (2003) ErbB-4: mechanism of action and biology. Exp Cell Res 284(1):66-77. doi:10.1016/s0014-4827(02)00100-3

15. PinkasKramarski R, Soussan L, Waterman H, Levkowitz G, Alroy I, Klapper L, Lavi S, Seger R, Ratzkin BJ, Sela M, Yarden Y (1996) Diversification of Neu differentiation factor and epidermal growth factor signaling by combinatorial receptor interactions. EMBO J 15(10):2452-2467

16. Siegel PM, Ryan ED, Cardiff RD, Muller WJ (1999) Elevated expression of activated forms of Neu/ErbB-2 and ErbB-3 are involved in the induction of mammary tumors in transgenic mice: implications for human breast cancer. EMBO J 18:2149-2164

17. Prigent SA, Gullick WJ (1994) Identification of c-erbb-3 bindingsites for phosphatidylinositol $3^{\prime}$-kinase and SHC using an EGF receptor c-ERBB-3 chimera. EMBO J 13(12):2831-2841

18. Munster PN, Marchion DC, Basso AD, Rosen N (2002) Degradation of HER2 by ansamycins induces growth arrest and apoptosis in cells with HER2 overexpression via a HER3, phosphatidylinositol 3 '-kinase-AKT-dependent pathway. Cancer Res 62(11):3132-3137

19. Vogel CL, Cobleigh MA, Tripathy D, John C. Gutheil, Lyndsay N. Harris, Louis Fehrenbacher, Dennis J. Slamon, Maureen Murphy, William F. Novotny, Michael Burchmore, Steven Shak, Stanford J. Stewart, Press M (2002) Efficacy and safety of trastuzumab as a single agent in first-line treatment of HER2overexpressing metastatic breast cancer. J Clin Oncol 20:719-726

20. Burris H, Yardley D, Jones S, Houston G, Broome C, Thompson D, Greco FA, White M, Hainsworth J (2004) Phase II trial of trastuzumab followed by weekly paclitaxel/carboplatin as first- 
line treatment for patients with metastatic breast cancer. J Clin Oncol 22(9):1621-1629. doi:10.1200/jco.2004.08.065

21. Slamon DJ, Jones BL, Shak S, Fuchs H, Paton V, Bajamonde A, Fleming TEW, Wolter J, Pegram M, Baselga J, Norton L (2001) Use of chemotherapy plus a monoclonal antibody against Her2 for metastatic breast cancer that overexpresses Her2. New Engl J Med 344(11):783-792

22. Baselga J, Rischin D, Ranson M, H. Calvert, E. Raymond, D.G. Kieback, S.B. Kaye, L. Gianni, A. Harris, T. Bjork, S.D. Averbuch, A. Feyereislova, H. Swaisland, F. Rojo, Albanell J (2002) Phase I safety, pharmacokinetic, and pharmacodynamic trial of ZD1839, a selective oral epidermal growth factor receptor tyrosine kinase inhibitor, in patients with five selected solid tumor types

23. Nahta R, Esteva FJ (2006) Molecular mechanisms of trastuzumab resistance. Breast Cancer Res 8(6):1-8. doi:10.1186/bcr1612

24. Romond EH, Perez EA, Bryant J, Suman VJ, Charles E. Geyer, Nancy E. Davidson, Elizabeth Tan-Chiu SM, Soonmyung Paik, Peter A. Kaufman, Sandra M. Swain, Thomas M. Pisansky, Louis Fehrenbacher, Leila A. Kutteh, Victor G. Vogel, Daniel W. Visscher, Greg Yothers, Robert B. Jenkins, Ann M. Brown, Shaker R. Dakhil, Eleftherios P. Mamounas, Wilma L. Lingle, Pamela M. Klein, James N. Ingle, and Norman Wolmark (2005) Trastuzumab plus adjuvant chemotherapy for operable HER2positive breast cancer. New Engl J Med 353(16):1673-1684

25. Piccart-Gebhart MJ, Procter M, Leyland-Jones B, Goldhirsch A, Untch M, Smith I, Gianni L, Baselga J, Bell R, Jackisch C, Cameron D, Dowsett M, Barrios CH, Steger G, Huang CS, Andersson M, Inbar M, Lichinitser M, Lang I, Nitz U, Iwata H, Thomssen C, Lohrisch C, Suter TM, Ruschoff J, Suto T, Greatorex V, Ward C, Straehle C, McFadden E, Dolci MS, Gelber RD (2005) Trastuzumab after adjuvant chemotherapy in HER2positive breast cancer. N Engl J Med 353(16):1659-1672

26. Barros FF, Abdel-Fatah TM, Moseley P, Nolan CC, Durham AC, Rakha EA, Chan S, Ellis IO, Green AR (2014) Characterisation of HER heterodimers in breast cancer using in situ proximity ligation assay. Breast Cancer Res Treat. doi:10.1007/s10549-0142871-4

27. Ellis IO, Galea M, Broughton N, Locker A, Blamey RW, Elston CW (1992) Pathological prognostic factors in breast-cancer.2. Histological type-relationship with survival in a large study with long-term follow-up. Histopathology 20(6):479-489

28. Elston CW, Ellis IO (1991) Pathological prognostic factors in breast cancer. I. The value of histological grade in breast cancer: experience from a large study with long-term follow-up. Histopathology 19(5):403-410

29. Galea MH, Blamey RW, Elston CE, Ellis IO (1992) The Nottingham prognostic index in primary breast cancer. Breast Cancer Res Treat 22(3):207-219

30. Abd Dalia M, El-Rehim GB, Pinder Sarah E, Rakha Emad, Paish Claire, Robertson John FR, Macmillan Douglas, Blamey Roger W, Ellis Ian O (2005) High-throughput protein expression analysis using tissue microarray technology of a large well-characterised series identifies biologically distinct classes of breast cancer confirming recent cDNA expression analyses. Int J Cancer 11:340-350. doi:10.1002/ijc.21004

31. Abd El-Rehim DM, Pinder SE, Paish CE, Bell JA, Rampaul RS, Rwblamey J, Robertson FR, Nicholson R, Ellis I (2004) Expression and co-expression of the members of the epidermal growth factor receptor (EGFR) family in invasive breast carcinoma. British J Cancer 91:1532-1542. doi:10.1038/sj.bjc.6602184

32. Rakha EA, El-Rehim DA, Paish C, Green AR, Lee AHS, Robertson JF, Blamey RW, Macmillan D, Ellis IO (2006) Basal phenotype identifies a poor prognostic subgroup of breast cancer of clinical importance. Eur J Cancer 42(18):3149-3156. doi:10. 1016/j.ejca.2006.08.015
33. Rakha EA, El-Sayed ME, Green AR, Lee AHS, Robertson JF, Ellis IO (2007) Prognostic markers in triple-negative breast cancer. Cancer 109(1):25-32. doi:10.1002/cncr.22381

34. Rakha EA, Elsheikh SE, Aleskandarany MA, Habashi HO, Green AR, Powe DG, El-Sayed ME, Benhasouna A, Brunet J-S, Akslen LA, Evans AJ, Blamey R, Reis-Filho JS, Foulkes WD, Ellis IO (2009) Triple-negative breast cancer: distinguishing between basal and nonbasal subtypes. Clin Cancer Res 15(7):2302-2310. doi:10.1158/1078-0432.ccr-08-2132

35. McShane LM, Altman DG, Sauerbrei W, Taube SE, Gion M, Clark GM (2006) REporting recommendations for tumor MARKer prognostic studies (REMARK). Breast Cancer Res Treat 100(2):229-235. doi:10.1007/s10549-006-9242-8

36. Holbro T, Beerli RR, Maurer F, Koziczak M, Barbas CF, Hynes NE (2003) The ErbB2/ErbB3 heterodimer functions as an oncogenic unit: erbB2 requires ErbB3 to drive breast tumor cell proliferation. Proc Natl Acad Sci USA 100(15):8933-8938. doi:10.1073/pnas. 1537685100

37. Naidu R, Yadav M, Nair S, Kutty MK (1998) Expression of c-erbB3 protein in primary breast carcinomas. $\mathrm{Br} \mathrm{J}$ Cancer 78(10):1385-1390. doi:10.1038/bjc.1998.689

38. Hsieh AC, Moasser MM (2007) Targeting HER proteins in cancer therapy and the role of the non-target HER3. Br J Cancer 97(4):453-457. doi:10.1038/sj.bjc.6603910

39. Smirnova T, Zhou ZN, Flinn RJ, Wyckoff J, Boimel PJ, Pozzuto M, Coniglio SJ, Backer JM, Bresnick AR, Condeelis JS, Hynes NE, Segall JE (2012) Phosphoinositide 3-kinase signaling is critical for ErbB3-driven breast cancer cell motility and metastasis. Oncogene 31(6):706-715. doi:10.1038/onc. 2011.275

40. Yarden Y (2001) The EGFR family and its ligands in human cancer: signalling mechanisms and therapeutic opportunities. Eur J Cancer 37:S3-S8

41. de Azambuja E, Cardoso F, de Castro G, Colozza M, Mano MS, Durbecq V, Sotiriou C, Larsimont D, Piccart-Gebhart MJ, Paesmans M (2007) Ki-67 as prognostic marker in early breast cancer: a meta-analysis of published studies involving 12155 patients. $\mathrm{Br}$ J Cancer 96(10):1504-1513. doi:10.1038/sj.bjc.6603756

42. Leek RD, Kaklamanis L, Pezzella F, Gatter KC, Harris AL (1994) BCL-2 in normal human breast and carcinoma, association with estrogen receptor-positive, epidermal growth-factor receptor-negative tumors and in situ cancer. Br J Cancer 69(1): 135-139. doi:10.1038/bjc.1994.22

43. Soltoff SP, Carraway KL, Prigent SA, Gullick WG, Cantley LC (1994) Erbb3 is involved in activation of phosphatidylinositol 3-kinase by epidermal growth-factor. Mol Cell Biol 14(6): $3550-3558$

44. Schoeberl B, Pace EA, Fitzgerald JB, Harms BD, Xu L, Nie L, Linggi B, Kalra A, Paragas V, Bukhalid R, Grantcharova V, Kohli N, West KA, Leszczyniecka M, Feldhaus MJ, Kudla AJ, Nielsen UB (2009) Therapeutically targeting ErbB3: a key node in ligand-induced activation of the ErbB receptor-PI3K axis. Sci Signal 2(77):ra31. doi:10.1126/scisignal.2000352

45. Desbois-Mouthon C (2010) The HER3/ErbB3 receptor: a promising target in cancer drug therapy. Gastroenterol Clin Biol 34(4-5):255-259. doi:10.1016/j.gcb.2010.03.002

46. Ku NO, Liao J, Omary MB (1997) Apoptosis generates stable fragments of human type I keratins. J Biol Chem 272(52): 33197-33203. doi:10.1074/jbc.272.52.33197

47. Caulin C, Salvesen GS, Oshima RG (1997) Caspase cleavage of keratin 18 and reorganization of intermediate filaments during epithelial cell apoptosis. J Cell Biol 138(6):1379-1394. doi:10. 1083/jcb.138.6.1379

48. Hattrup CL, Gendler SJ (2006) MUC1 alters oncogenic events and transcription in human breast cancer cells. Breast Cancer Res 8(4):R37. doi:10.1186/bcr1515 
49. Mukhopadhyay P, Chakraborty S, Ponnusamy MP, Lakshmanan I, Jain M, Batra SK (2011) Mucins in the pathogenesis of breast cancer: implications in diagnosis, prognosis and therapy. Biochimica Et Biophysica Acta-Reviews on Cancer 1815(2): 224-240. doi:10.1016/j.bbcan.2011.01.001

50. Grunt TW, Saceda M, Martin MB, Lupu R, Dittrich E, Krupitza G, Harant H, Huber H, Dittrich C (1995) Bidirectional interactions between the estrogen-receptor and the c-Erbb2 signalling pathways-heregulin inhibits estrogenic effects in breast cancer cells. Int J Cancer 63(4):560-567. doi:10.1002/ijc.2910630417

51. Melanie Spears KJT, Munro Alison F, Cunningham Carrie A, Mallon Elizabeth A, Twelves Chris J, Cameron David A, Thomas Jeremy, Bartlett John MS (2011) In situ detection of HER2:HER2 and HER2:HER3 protein-protein interactions demonstrates prognostic significance in early breast cancer. Breast Cancer Res Treat. doi:10.1007/s10549-011-1606-z
52. Dati C, Antoniotti S, Taverna D, Perroteau I, Debortoli M (1990) Inhibition of c-Erbb2 oncogene expression by estrogens in human breast-cancer cells. Oncogene 5(7):1001-1006

53. Mittendorf EA, Liu Y, Tucker SL, McKenzie T, Qiao N, Akli S, Biernacka A, Meijer L, Keyomarsi K, Hunt KK (2010) A novel interaction between HER2/neu and cyclin E in breast cancer. Oncogene 29(27):3896-3907. doi:10.1038/onc.2010.151

54. Pietras RJ, Pegram MD, Finn RS, Maneval DA, Slamon DJ (1998) Remission of human breast cancer xenografts on therapy with humanized monoclonal antibody to HER-2 receptor and DNA-reactive drugs. Oncogene 17(17):2235-2249. doi:10.1038/ sj.onc. 1202132

55. Winters ZE, Leek RD, Bradburn MJ, Norbury CJ, Harris AL (2003) Cytoplasmic p21WAF1/CIP1 expression is correlated with HER-2/ neu in breast cancer and is an independent predictor of prognosis. Breast Cancer Res 5(6):R242-R249. doi:10.1186/bcr654 